Eduvest - Journal of Universal Studies

Volume 1 Number 11, November 2021

p- ISSN 2775-3735 e-ISSN 2775-3727

\title{
RELATIONSHIP OF COMPETENCE (KNOWLEDGE, ATTITUDE AND BEHAVIOR) WITH READINESS TO APPLY EVIDENCE-BASED PRACTICE IN NURSE PROFESSION STUDENTS
}

\section{Fitroh Asriyadi, Arief Budiman}

Muhammadiyah University of East Kalimantan, Indonesia

E-mail: fa142@umkt.ac.id, ab783@umkt.ac.id

\begin{tabular}{|c|c|}
\hline ARTI & ABSTRACT \\
\hline $\begin{array}{l}\text { Received: } \\
\text { October, } 26^{\text {th }} \\
2021 \\
\text { Revised: } \\
\text { November, } 17^{\text {th }} \\
2021 \\
\text { Approved: } \\
\text { November, 19th } \\
2021\end{array}$ & $\begin{array}{l}\text { Indonesia is currently in the 21st century where the } \\
\text { learning process is developing, education is expected to be } \\
\text { able to produce human resources capable of } \\
\text { implementing programs and solving problems together in } \\
\text { a wise, peaceful, and intelligent way. ). This research is a } \\
\text { type of quantitative research with a correlational analytic } \\
\text { design and uses a cross-sectional design where in this } \\
\text { design the researcher wants to reveal the relationship } \\
\text { between readiness to apply Evidence-Based Practice with } \\
\text { knowledge, attitudes, and behavior in Nursing } \\
\text { Professional Students, Muhammadiyah University of East } \\
\text { Kalimantan. The population in this study is all students } \\
\text { who will complete the academic program of S1 Nursing } \\
\text { Science at the University of Muhammadiyah East } \\
\text { Kalimantan and who will continue the profession of Ners } \\
\text { at the University of Muhammadiyah East Kalimantan, and } \\
\text { the number of samples in this researcher as many as } 115 \text {, } \\
\text { using the Non Probability Sampling method with sampling } \\
\text { techniques used total sampling. This research will be } \\
\text { carried out by the UMKT campus and Wahana learning of } \\
\text { Ners professional practice. The conclusion of this study is } \\
\text { the characteristics of respondents based on semester i.e. } \\
\text { students are undergoing semester I education (one), the } \\
\text { majority of respondents aged 17-25 years as many as } 92\end{array}$ \\
\hline
\end{tabular}

Fitroh Asriyadi, Arief Budiman (2021). Relationship of Competence (Knowledge, Attitude and Behavior) With Readiness to Apply Evidence-Based Practice in Nurse Profession Students. Journal Eduvest. 1(11): 1329-1340

How to cite:

E-ISSN:

Published by: $\quad$ https://greenpublisher.id/ 


\begin{tabular}{ll}
\hline & $\begin{array}{l}\text { respondents, gender is mostly female as many as } 76 \\
\text { respondents. }\end{array}$ \\
\hline KEYWORDS & $\begin{array}{l}\text { Competence, Readiness, Preparation, Evidence-Based Paractice, } \\
\text { NERS Students }\end{array}$ \\
\hline CC (D) (O) & $\begin{array}{l}\text { This work is licensed under a Creative Commons } \\
\text { Attribution-ShareAlike 4.0 International }\end{array}$ \\
\hline
\end{tabular}

\section{INTRODUCTION}

This development of education is by the goal of the sustainable development goal (SDG'S) in goal 4 which ensures a fair and inclusive quality of education and increases lifelong learning opportunities for all. The strategy that has been set by SDG at point 8 is to improve the quality of higher education. The efforts made in updating and improving science and technology are by the Minister of Education and Culture, No. 49 of 2014 article 11 concerning national standards of higher education, by the regulations of the Minister of Education and Culture, the characteristics of the learning process are expected to consist of interactive, integrative, holistic, contextual, collaborative, effective and scientific, what is meant by scientific is the learning process carried out based on approaches scientific.

The scientific approach taken in health education institutions aims to realize professional services based on ability through student curiosity during the educational process and students are expected to be able to provide evidence-based services (Simamora \& Kep, 2009). Evidence-based practice is a competency that must be possessed by health workers to be able to provide services in health actions so that they remain up to date so that evidence-based practice must be integrated into the nursing curriculum and can assist in making clinical action decisions effectively.

The Faculty of Health and Pharmacy Sciences at the Muhammadiyah University of East Kalimantan, which was formerly known as the Muhammadiyah Samarinda College of Health Sciences, is one of the educational institutions that has been registered as a member of AIPNI, where UMKT has developed an evidence-based practice in the nursing professional nursing program so that students can apply articles or journal that is evidence-based when in clinical practice. This can be seen in one of the missions of the Muhammadiyah University of East Kalimantan, namely, developing research with priority on social issues, especially unemployment and poverty as well as the environment.

The Muhammadiyah University of East Kalimantan has collaborated with several hospitals in Samarinda in the implementation of clinical practice for the nursing profession. Clinical practice is said to be key in building nurse student competencies because nurse students can apply theoretical knowledge and develop skills to provide care to their patients directly (Yang, 2013).

Preliminary study of researcher interviews with 8th-semester students at the Muhammadiyah University of East Kalimantan, as many as 10 respondents obtained information that they know what is meant by evidence-based practice, in the process of searching for journals they usually use Google Scholar, PubMed but they still do not understand how to determine an evidence-based practice journal. 8 out of 10 respondents said that they would apply articles that are evidence-based practice in practice.

Based on the description of the phenomenon above, there are several factors related to the readiness to apply evidence-based practice to nursing students. Therefore, researchers are interested in researching "Factors related to Readiness to Apply Evidence- 
Based Practice in Nursing Professional Students, University of Muhammadiyah East Kalimantan in 2020"

The purpose of this study was to analyze factors related to the readiness to apply evidence-based practice to nursing professional students in 2019 at Muhammadiyah University of East Kalimantan. By identifying the characteristics of respondents (semester, age, and gender) in nursing professional students at the Muhammadiyah University of East Kalimantan. Identifying knowledge, attitudes, behavior in nursing professional students in 2019 at Muhammadiyah University of East Kalimantan. Identifying readiness for application to nursing professional students in 2019 at Muhammadiyah University of East Kalimantan and analyzing the relationship between knowledge and readiness to apply evidence-based practice to nursing professional students in 2019 at Muhammadiyah University of East Kalimantan.

Research urgency: Evidence-based practice is a strategy to acquire knowledge and skills to increase positive behavior by combining the best research evidence so that evidence-based practice can be applied to nursing practice and make better health care decisions (Bostwick, 2003).

Knowledge of the concept of evidence-based practice is an important thing that nursing students must have later, this is because knowledge is a factor that can affect the quality of service to patients. Nursing students need to be aware of what evidence-based practice means and what attitude they must take so that the concept can be applied correctly in the field of practice (Oktiayuliandri, 2015). Nugraha (2015) attitude is needed by students to be able to behave according to the inclination of their heart. Behavior in the use of evidence-based practice where students systematically find, assess, and use the latest valid research findings as a basis for determining clinical decisions to be given to patients.

(Slameto, 2010) although nursing students show a positive attitude in applying evidence-based, the ability to search scientific literature is still lacking. Some literature shows that evidence-based practice is still a new thing for nursing students, therefore the integration of evidence-based into the nursing curriculum and how to integrate evidencebased into clinical practice is very important (Ashktorab, Pashaeypoor, Rassouli, \& Alavi-Majd, 2015).

\section{RESEARCH METHOD}

This research is a type of quantitative research with a correlational analytic design and uses a cross-sectional design where in this design the researcher wants to reveal the relationship between readiness to implement Evidence-Based Practice with knowledge, attitudes, and behavior in Nursing Professional Students, Muhammadiyah University, East Kalimantan. The population in this study are all students who will complete their undergraduate nursing education at the Muhammadiyah University of East Kalimantan and who will continue the nursing profession at the Muhammadiyah University of East Kalimantan, and the number of samples in this researcher is 115, using the NonProbability Sampling method with the technique of sampling used total sampling. This research will be carried out by the UMKT campus and the Nurses' Professional Practice Learning Center. Univariate Analysis This study aims to analyze in the form of explaining or describing the characteristics of each variable being studied. The course of the research that has been carried out is divided into several stages, namely: Research 
Preparation Stage by submitting a research proposal. Prepared the Evidence-based practice Questionnaire from Upton and Readiness from Melnyk. Taking care of licensing, conducting a preliminary study to obtain primary data in the form of interviews with 10 students and secondary data obtained through the UMKT Academic Administration Section (BAA) which is used as reference material. Implementation Phase This research was conducted at the UMKT campus and the nurse's student practice area adjusted the schedule that had been set. The research was carried out by the researcher with the help of several fellow students. Before the questionnaire was given, informed consent was given. After the time limit has been set, the researcher collects data for further editing (data editing) where the researcher checks the correctness of the data that has been collected. Next, the researcher coding sheet (code sheet) on the questionnaire sheet that has been filled out by the respondent.

The final stage is compiling a report on the results of the entry researcher (entering data) that has been collected into a table in Microsoft Office and analysis applications. enter research data and do the cleaning. Discussion of research results based on existing data is connected with related theories and presents research results.

\section{RESULT AND DISCUSSION}

\section{A. Characteristics of Respondents} results:

Data processing that has been carried out using computerization has the following

Table 1 Characteristics of respondents by semester, age, and gender.

\begin{tabular}{lcc}
\hline \multicolumn{1}{c}{ Characteristics } & Frequency & Percentage \% \\
\hline Semester & & \\
Semester 1 & 113 & 100.0 \\
Age & & \\
$17-25$ & 92 & 81.4 \\
$26-35$ & 16 & 14.2 \\
$36-45$ & 5 & 4.4 \\
Gender & & \\
Woman & 76 & 67.3 \\
Man & 37 & 32.7 \\
\hline
\end{tabular}

In the presentation of table 1 above, it shows that based on the respondent's semester, the semester that was taken was Semester 1 as many as 113 respondents $(100 \%)$. based on the age of the respondents, namely the majority aged 17-25 years as many as 92 respondents $(81.4 \%)$. the majority of respondents' gender is female as many as 76 respondents $(67.3 \%)$. Based on the results of the characteristics of respondents in the form of semesters According to the Ministry of Health (2018) semester is the length of effective learning activities for 6 months both in the form of theory and laboratory practice in professional education, nurses apply all their learning in clinical practice and in the community in improving technical, intellectual skills, based on real theory and able to implement a nursing process approach that is supported by the practical basics of evidence-based nursing practice to achieve the goal of successful care to be provided to patients (Indonesia, 2016).

The researcher argues that based on the description and data results since the beginning of the semester, nurses' professional education has targeted students to improve problem-solving skills in nursing actions and involve EBP in it to achieve the best nursing actions and in the future become partners who can respond to the growth and development of science and technology. to achieve the best health care. Based on the 
results of the characteristics of the respondents in the form of age. Age is often associated with a person's level of maturity in thinking and behaving, this is usually associated with increasing age, the experience and responsibility in carrying out tasks increases, then the older the person will increase the ability to make decisions, control emotions, think rationally and tolerance for the views of others so that it also affects the increase in motivation.

Based on the description and results of the data, the researcher argues that age affects a person to continue to find out, understand, and accept scientific developments so that the ability to analyze will be better and then be able to apply the latest sciences. Based on the results of the characteristics of the respondents in the form of gender. In the research of Yanti \& Warsito (2013) and Lippa (2010), the nature of women is more patient, gentle, and caring. The nature of men is more competitive, dominant, responsible, independent, and unemotional, although gender will provide different motivations, the male sex has a greater desire than women because the male responsibility is greater. Based on the description and results of the data, researchers argue that gender differences influence individual behavior in implementing something in their lives regardless of other factors such as education, environment, or experience.

\section{B. Univariate Analysis} Student Behavior Variables

Table 2 Frequency Distribution by Behavior

\begin{tabular}{lccc}
\hline & Behavior & Frequency & Percentage \% \\
\hline Good & & 66 & 58.4 \\
Not Good & & 47 & 41.6 \\
\hline & Total & $\mathbf{1 1 3}$ & $\mathbf{1 0 0 . 0}$ \\
\hline
\end{tabular}

Source: Primary Data 2020

The presentation of the data in the table above shows that based on the behavior of respondents who have good behavior as many as 66 respondents $(58.4 \%)$. Research by Ammori, Raddaha, Dsouza, et al., (2014) shows that respondents have a positive response to the behavior of using EBP with years of experience having better practice behavior. The behavior in implementing real evidence-based practice is when health practitioners are able to assess the situation around or the environment around the patient, the appearance of the patient, and the actions of the clinician to be given to the patient in accordance with the focus of clinical questions that will be answered in relation to the patient's condition (Tilson et al., 2011) (Legita, 2012). The results of research by (AbuRuz, Hayeah, Al-Dweik, \& Al-Akash, 2017) reveal that respondents with best practice behavior values are always followed by good attitudes and knowledge values as well. The holistic learning process is divided into three learning domains, namely the cognitive, affective, and psychomotor domains through these domains enable individuals to develop abilities. In nursing professional education, clinical learning provides opportunities for students to develop attitudes, psychomotor skills, knowledge, time management, and problem-solving skills (Rahyubi, 2014. Reilly, 2002. Desvitasari, 2016). Based on the description and results of the data above, the researcher argues that positive behavior can be seen in terms of expertise or skills in carrying out clinical actions against patients, this is a reflection of the cognitive and affective domains obtained from formal education or previous clinical practice learning.

Attitude Variable The results obtained in the univariate analysis are the majority of students have a positive attitude as many as 62 respondents (54.9\%) and based on the readiness to apply the evidence-based practice, respondents have good readiness, namely as many as 57 respondents $(50.4 \%)$. which consists of thinking, feeling, behaving, and 
responding to a command or cognitive object as well as attitude is something that can be learned, determines how individuals react to situations, and determines what individuals are looking for in life. Attitudes are related to affection (deep feelings) that are positive or negative and relate to certain objects. A negative attitude is an attitude that does not support or oppose the object. Similar to positive attitudes, negative attitudes are also influenced by individual personal experiences, cultural influences, mass media religious institutions, educational institutions, emotional factors, and the influence of other people who are considered important (Yusvanita, 2019). The results of research by AbuRuz, Hayeah, Al-Dweik, and Al-Akash (2017) say that attitudes towards evidence-based practice have the highest average score, which means that respondents have a positive attitude. However, they do not put their positive attitude and evidence-based practice into daily practice. Based on the results of the study and the description above, the researcher assumes that a person's attitude can change according to his heart's desires and what he learns in his life. Based on the readiness of the implementation of evidence-based practice, most of the respondents have good readiness, readiness for the application of evidence-based practice is an attitude that can support nursing professional students to be able to participate creatively towards organizational goals in the field of practice. The readiness of nursing professional students in implementing evidence-based practice may include several factors related to their attitudes towards beliefs about evidence-based practice, namely workplace culture and the need for information (Makki, Salleh, Memon \& Harun, 2015; Saunders \& Vehvilainen-Julkunen , 2015). Harun, Herliani \& Setyawati (2019), which states that the readiness to implement evidence-based practice in question is looking for research results, evaluating research results, and applying them. Research results can be found through scientific magazines or also called journals both online and offline. Based on the results of the study and the description above, the researchers assume that the readiness to apply evidence-based practice can be seen from how often they seek and read the best research results. The more they get used to finding and reading the best research results, the better prepared they will be to apply them.

\section{Knowledge Variable}

Table 3. Knowledge and Readiness of Evidence-based Practice for Nurse Profession Students at Muhammadiyah University of East Kalimantan.

\begin{tabular}{lcc}
\hline \multicolumn{1}{c}{ Variable } & Frequency & Percentage (\%) \\
\hline Knowledge & & \\
Well & 50 & 44.2 \\
Pretty good & 49 & 43.4 \\
Not good & 14 & 12.4 \\
\hline Total & $\mathbf{1 1 3}$ & $\mathbf{1 0 0 . 0}$ \\
\hline
\end{tabular}

Source: Primary Data for 2020.

The presentation of data for the knowledge of nursing professional students shows that most of them have good knowledge as many as 50 respondents (44.2\%), 49 respondents have good knowledge (43.4\%), and 14 respondents $(12.4 \%)$ have poor knowledge. The presentation of the data in table 2 shows that most of them have good knowledge as many as 50 respondents (44.2\%), knowledge is quite good as many as 49 respondents (43.4\%), and poor knowledge as many as 14 respondents (12.4\%). 
Knowledge is a competency that must be possessed by nursing professional students in providing quality care to patients. Nurse profession students' knowledge of evidencebased practice is not only based on concepts, but also requires knowledge of how to apply evidence-based practice directly to patients (Melnyk, Ford, Long, \& Overholt, 2014. Harun, Herliani, \& Setyawati, 2019 ).

According to Melnyk, Overholt, \& Mays (2008), knowledge in applying evidencebased practice to students before looking for journals to apply to patients, they must make PICO questions (P: problem, I: intervention, C: comparison or control, O: results), discusses evidence-based practice from research studies with colleagues informally, is able to evaluate the results of the given intervention, reads and critically assesses research, is able to search for evidence-based practice guidelines on the internet (Cochrane Library, NCBI, Google Scholar, etc.) ) in determining the intervention to be given.

In the data presentation, table 2 shows that most of them have good readiness to implement evidence-based practice as many as 57 respondents $(50.4 \%)$, poor readiness as many as 56 respondents $(49.6 \%)$. Readiness in applying evidence-based practice is the condition of a person who makes himself ready to provide nursing actions with the knowledge and skills he has such as conducting a literature search and evaluating evidence, knowledge is one of the keys in implementing evidence-based practice when in practice so that he can help contribute productively to achieve goals in providing nursing actions to patients while in practice (Makki, Salleh, Memon, \& Harun, 2015. Slameto, 2010. AbuRuz, Hayeah, Al-Dweik and Al-Akash 2017).

Based on the description above, the researcher argues that in applying evidencebased practice students already have the skills to conduct a literature search and when in clinical practice they are required to have the knowledge and readiness to apply the best research evidence from previous research findings directly to patients so that students able to contribute productively in providing nursing care and can evaluate it directly in order to achieve the desired goals.

Variables of Readiness to Implement Evidence-Based Practice

Table 4. Distribution of Frequency Based on Readiness to Implement Evidence-Based Practice.

\begin{tabular}{lccc}
\hline \multicolumn{2}{c}{ Deployment Readiness } & Frequency & Percentage \% \\
\hline Good & 57 & 50.4 \\
Not Good & Total & 56 & 49.6 \\
\hline \multicolumn{2}{c}{} & $\mathbf{1 1 3}$ & $\mathbf{1 0 0 . 0}$ \\
\hline
\end{tabular}

Source: Primary Data for 2020.

The presentation of the data in the table above shows that based on the readiness to implement evidence-based practice, respondents with good readiness were 57 respondents $(50.4 \%)$. The readiness of nursing professional students in implementing evidence-based practice includes behavior in their skills related to evidence-based practice such as searching for research results both online and through scientific magazines (journals), evaluating research results, and applying them. Learning-related to evidence-based practice in students can encourage behavior and readiness in carrying out nursing care related to previous findings (Saunders \& Vehvilainen-Julkunen, 2015. Harun, Herliani, \& Setyawati, 2019. Hart et al., 2008. AbuRuz, Hayeah, Al-Dweik, and Al-Akash, 2017. Damayanti \& Bachtiar, 2020. ).

Based on the description and data results, the researcher argues that the readiness to apply evidence-based practice to students begins with positive behavior in seeking the best research results which are then applied and evaluated so that they can be taken into 
consideration in determining the best course of action for patients. It also allows students to connect theory with practice in treating patients directly.

Bivariate Analysis

Relationship between Behavior and Readiness to Apply Evidence-Based Practice.

Table 5. Relationship between Behavior and Readiness to Apply Evidence-Based Practice

\begin{tabular}{|c|c|c|c|c|c|c|c|c|}
\hline \multirow{3}{*}{$\begin{array}{l}\text { Variable } \\
\text { Behavior }\end{array}$} & \multicolumn{4}{|c|}{$\begin{array}{l}\text { EBP Implementation } \\
\text { Readiness }\end{array}$} & \multirow{2}{*}{\multicolumn{2}{|c|}{ Total }} & \multirow{3}{*}{$P$ value } & \multirow[t]{3}{*}{$O R$} \\
\hline & \multicolumn{2}{|c|}{ Good } & \multicolumn{2}{|c|}{ Not Good } & & & & \\
\hline & $\mathbf{N}$ & $\%$ & $\mathbf{N}$ & $\%$ & $\mathbf{N}$ & $\%$ & & \\
\hline Good & 39 & 34.5 & 27 & 23.9 & 66 & 58.4 & & 2.327 \\
\hline Not Good & 18 & 15.9 & 29 & 25.7 & 47 & 41.6 & 0.047 & $(1.082-$ \\
\hline Total & 57 & 50.4 & 56 & 49.6 & 113 & 100.0 & & $5.006)$ \\
\hline
\end{tabular}

Source: Primary Data for 2020

The results of the research above on the relationship between behavior and readiness for the application of evidence-based practice at the Muhammadiyah University of East Kalimantan with a total of 113 respondents obtained the majority have good behavior with readiness to implement EBP obtained 39 respondents $(34.5 \%)$. The results of the statistical test showed a p-value $0.047<$ from the alpha value of 0.05 which means Ha failed to reject that there is a significant relationship between behavior and readiness to implement evidence-based practice in nursing professional students at Muhammadiyah University of East Kalimantan.

According to Zan PH, (2010). Notoadmodjo S, (2010). Reilly \& Oermann, (2002), behavior arises as a result of several things, including because of the reciprocal relationship between stimulus and response which is better known as response stimulus. The relationship between stimulus and response will form new behavior patterns, but all responses are highly dependent on individual characteristics. Before someone adopts a new behavior, the person must go through a sequential process including one awareness (awareness), two interests (feeling interested), third evaluation (evaluating), fourth trial (trial), and fifth adoption (adaptation). The results of research by Perez-Campos et al., (2014) and research by Brown et al., (2008) state that positive knowledge and attitudes shape good behavior and skills as well. However, this is different from the research of Manjula et al., (2018) and Zhou (2016) in this study, respondents with positive attitudes but lack knowledge and behavior towards the application of evidence-based practice.

Based on the description and results of the data, the researcher argues that the behavior of implementing good evidence-based practice is the result of good knowledge and positive attitudes, this is by three learning domains, namely cognitive, affective, and psychomotor which are interrelated. The formation of the behavior itself starts from how the student perceives an object, prepares physically and emotionally, and learns skills or actions that will be carried out through standardized procedures and mechanisms, and can work and innovate in acting. Unfavorable behavior with good readiness obtained 18 respondents (15.9\%) while those who had poor readiness were 29 respondents (25.9\%).

In the study, Ez Elarab et al., (2012) stated that nurses with low clinical skills had little EBP application, this was due to a lack of information sources and overcrowded working hours as for other factors such as age, experience, and education level. Ez Elarab 
et al., (2012) also conveyed that nursing education believes by applying evidence-based practice will update or strengthen research, theory, and clinical skills. Unfortunately, many nurses in practice do not understand the concept of evidence-based practice or how to apply the EBP approach to clinical activities in general. Meanwhile, according to Ryan in Herliani et al., (2018), it is stated that graduates of nursing education have fewer opportunities to practice EBP and so are less confident in using EBP independently.

According to Ligita (2012), that the lack of learning methods about the evidencebased practice at the time of undergraduate nursing college so that the ability of nursing professional students in search for scientific literature is still very low or it can be said that they do not have sufficient knowledge and readiness so that in applying evidencebased practice is still lacking. Based on the description and results of the data above, the researcher believes that poor behavior is caused by several factors, namely lack of opportunity, lack of understanding regarding the application of EBP in clinical action, or lack of confidence. Readiness to apply the good evidence-based practice, researchers argue that there is motivation from individuals to develop their abilities related to the field of interest.

Relationship between attitude and readiness to implement evidence-based practice

Table 6. Relationship between attitudes and readiness to implement evidence-based practice at Muhammadiyah University of East Kalimantan

\begin{tabular}{|c|c|c|c|c|c|c|c|c|}
\hline \multirow{3}{*}{$\begin{array}{c}\text { Variable } \\
\text { Attitude }\end{array}$} & \multicolumn{4}{|c|}{ EBP Implementation Readiness } & \multirow{2}{*}{\multicolumn{2}{|c|}{ Total }} & \multirow{3}{*}{ P Value } & \multirow{3}{*}{ OR } \\
\hline & \multirow{2}{*}{$\frac{\text { Good }}{\mathrm{N}}$} & \multicolumn{3}{|c|}{ Not Good } & & & & \\
\hline & & $\%$ & $\mathrm{~N}$ & $\%$ & $\mathrm{~N}$ & $\%$ & & \\
\hline Positive & 38 & 33.6 & 24 & 21.2 & 62 & 54.9 & 0.019 & $\begin{array}{r}2.667 \\
(1.242-\end{array}$ \\
\hline Negative & 19 & 16.8 & 32 & 28.3 & 51 & 45.1 & & $5.724)$ \\
\hline Total & 57 & 50.4 & 56 & 49.6 & 113 & 100 & & \\
\hline
\end{tabular}

Source: Primary Data for 2020

Based on table 3, the results of the bivariate analysis above are positive attitudes and good EBP implementation readiness, namely, there are 38 respondents (33.6\%). From table 3 based on the results of bivariate analysis, the results of statistical tests show a p-value of 0.019 which is smaller than the alpha value of 0.05 which means rejecting the null hypothesis (H0), which can be concluded that there is a significant relationship between attitudes and readiness to apply evidence-based practice to students. nurse profession at the Muhammadiyah University of East Kalimantan.

Hart, Eaton, Buckner, et al., (2008) explained that the attitude of nurses is one of the most important factors in implementing EBP. Nurses with positive attitudes are more likely to use evidence-based research (EBP) in clinical practice. Nurses who believe that EBP can provide the best outcomes for patients will improve their clinical practice inpatient care. Respondents in the study of Campos et al., (2014) got the highest score on the EBPQ attitude subscale with a mean value of 5.35, indicating a good tendency to use research evidence and belief in EBP.

Several studies (Nagy et al. 2001, Sanzero-Eller et al. 2003, Wallin et al. 2003, Milner et al. 2006) show that nurses' positive attitudes towards evidence-based practice are relevant to the application of evidence-based practice in daily clinical practice. them (Eizenberg, 2011). Based on the results of the study and the description above, the 
researcher assumes that knowledge and experience must be supported by a positive attitude so that when a person has sufficient knowledge and experience, his attitude will be receptive to applying evidence-based studies.

Harun, Herliani, and Setyawati (2019) explain that nurses have a negative attitude towards research and are the lowest compared to other health workers. Based on the description above, the researcher assumes that there are still nurses who have negative attitudes towards research because nurses are still not exposed to the best research and have not gotten used to using it. This study is also in line with research by Hart et al (2008) and Knops et al (2009) in Ligita (2012) which states that almost all respondents have a positive attitude towards the implementation of EBP because respondents believe that EBP can improve the quality of care for patients and research (scientific evidence). assist them in making clinical decisions. By applying the concept of EBP, clinicians realize that the results of the research carried out are useful in everyday clinical practice.

There are many reasons for failure to implement evidence-based practice or EBP including, lack of knowledge about evidence-based strategies, misperceptions or negative attitudes about evidence-based research and care, lack of knowledge about how to find and assess evidence, demanding patient workloads, organizational constraints (lack of administrative support or incentives). Based on the description above, the researcher assumes that in the application of EBP the respondents are not ready because of many things, one of which is a misperception of the research so that it raises a negative attitude and the respondent has a positive attitude but the readiness for the application of EBP is not good due to obstacles in the institution such as the lack of support for nurses towards current evidence-based practices (Ez elarab et al., 2012).

\section{Relationship between knowledge and readiness to implement evidence-based practice}

Table 7. The relationship between knowledge and readiness for the application of evidence-based practice in nursing professional students at Muhammadiyah University of

East Kalimantan

\begin{tabular}{cccccccc}
\hline \multirow{2}{*}{ Variable } & \multicolumn{2}{c}{ EBP Implementation Readiness } & \multicolumn{2}{l}{ Total } & \multirow{2}{*}{ P value } \\
\cline { 2 - 5 } Good & \multicolumn{2}{c}{ Not Good } & & \\
\hline Knowledge & $\mathrm{N}$ & $\%$ & $\mathrm{~N}$ & $\%$ & $\mathrm{~N}$ & $\%$ & \\
\hline Well & 32 & 28.3 & 18 & 15.9 & 50 & 44.2 & \multirow{2}{*}{0.024} \\
Pretty good & 21 & 18.6 & 28 & 24.8 & 49 & 43.4 & \\
Not good & 4 & 3.5 & 10 & 8.8 & 14 & 12.4 & \\
\hline Total & $\mathbf{5 7}$ & $\mathbf{5 0 . 4}$ & $\mathbf{5 6}$ & $\mathbf{4 9 . 6}$ & $\mathbf{1 1 3}$ & $\mathbf{1 0 0 . 0}$ & \\
\hline
\end{tabular}

Source: Primary Data for 2020.

The results of the Chi-Square test analysis showed that the p-value was 0.024 $<0.05$, which means Ho was rejected, it can be concluded that there is a significant relationship between knowledge and readiness to implement evidence-based practice in nursing professional students at Muhammadiyah University of East Kalimantan.

Based on the results of table 3 cross-tabulation conducted between knowledge and readiness for the application of evidence-based practice, it was obtained that from 113 respondents, who had good knowledge with readiness to implement good evidence-based practice were 32 respondents $(28.3 \%)$ while those who had good knowledge with the readiness of the implementation of evidence-based practice is not good as many as 8 
respondents $(15.9 \%)$. Based on the results of the analysis using the Chi-Square test, the results obtained $p$-value $=0.024<0.05$, which means Ho is rejected, meaning that there is a significant relationship between knowledge and readiness to apply evidence-based practice to nursing professional students at Muhammadiyah University of East Kalimantan.

This research is in line with the research that has been conducted by Harun, Herliani, \& Setyawati (2018), where the results of the analysis of the knowledge relationship between nurses' professional program students in the application of evidencebased practice in managed patients obtained a significant relationship between student knowledge in applying evidence-based practice with $\mathrm{p}$-value $=0.01<0.05$.

Knowledge, experience in applying evidence-based practice, level of education, and age indicate a positive influence on the readiness to apply evidence-based practice to a person. The higher a person's education level, the higher the knowledge about the concept of evidence-based practice that one has so that in applying evidence-based practice the better (Azmoude, Farkhondeh, Ahour, \& Kabirian, 2017) (Saunders \& Vehviläinen-Julkunen, 2016).

This is supported by research by Elysabeth et al. (2014), which states that knowledge greatly influences a person in critically assessing scientific work. This is because education acts as something that influences a person's behavior in making changes to the knowledge, attitudes, values, and skills possessed in assessing scientific work.

Based on the description above, the researcher believes that knowledge about the concept of evidence-based practice is the result of the level of education and behavior of students who continue to update their knowledge so that students are able to prepare themselves in providing nursing care to patients based on the latest research evidence so that later these students are expected to become a professional nurse and able to apply the latest sciences.

The conclusion of this study is the characteristics of respondents based on semesters, namely students who are studying in the semester I (one), the majority of respondents aged 17-25 years are 92 respondents, gender is mostly female as many as 76 respondents. The behavioral variables of nursing profession students at the Muhammadiyah University of East Kalimantan have good behavior as many as 66 respondents and based on readiness for the application of evidence-based practice have good readiness as many as 57 respondents. There is a significant relationship between behavior and readiness for the application of evidence-based practice in nursing professional students with a $\mathrm{p}$-value $=0.047<0.05$ Variable The attitude of the respondents is positive with a total of 62 respondents, the readiness to apply evidencebased practice respondents is good, as many as 57 respondents. There is a significant relationship between attitude and readiness to implement evidence-based practice with pvalue $=0.019<0.05$. Variable Knowledge of nursing professional students at the Muhammadiyah University of East Kalimantan from 113 respondents mostly had good knowledge as many as 50 respondents $(44.2 \%)$ and for readiness to apply evidence-based practice to nursing profession students, most of them had good readiness, namely 57 respondents $(50.4 \%)$. The results of the chi-square test obtained p-value $=0.024<0.05$, there is a significant relationship between knowledge and readiness to implement evidence-based practice in nursing professional students.

\section{CONCLUSION}

Based on the results of this study, it can be concluded that reticuline compounds 
have good stability, followed by geranyl-caproate which is seen from the value of binding energy $(\Delta \mathrm{G})$. Good secondary metabolite compounds of Annona muricata plant were shown by reticuline with a value $(\Delta \mathrm{G})$ of $-9.91 \mathrm{kcal} / \mathrm{mol}$. Furthermore, the observation of hydrogen bonding and amino acid scyllitol showed the similarity of 1 of 2 residues possessed by celecoxib, which previously had known anticancer activity. It can be concluded that curcumin and its analogues have potential as anticancer, and can be used for further drug development related to anticancer.

\section{REFERENCES}

AbuRuz, Mohannad Eid, Hayeah, Haneen Abu, Al-Dweik, Ghadeer, \& Al-Akash, Hekmat Yousef. (2017). Knowledge, attitudes, and practice about evidence-based practice: a Jordanian study. Health Science Journal, 11(2), 1.

Ashktorab, Tahereh, Pashaeypoor, Shahzad, Rassouli, Maryam, \& Alavi-Majd, Hamid. (2015). Nursing students' competencies in evidence-based practice and its related factors. Nursing and Midwifery Studies, 4(4).

Azmoude, Elham, Farkhondeh, Fereshteh, Ahour, Maryam, \& Kabirian, Maryam. (2017) Knowledge, practice and self-efficacy in evidence-based practice among midwives in East Iran. Sultan Qaboos University Medical Journal, 17(1), e66.

Indonesia, Asosiasi Intistitusi Pendidikan Ners. (2016). Kurikulum Inti Pendidikan Ners Indonesia 2015. Cetakan Pe. Jakarta: Asosiasi Institusi Pendidikan Ners Indonesia (AIPNI).

Legita, Titan. (2012). Pengetahuan, Sikap dan Kesiapan Perawat Klinisi Dalam Implementasi Evidence-Base Practice. Ners Jurnal Keperawatan, 8(1), 84-97.

Saunders, Hannele, \& Vehviläinen-Julkunen, Katri. (2016). The state of readiness for evidence-based practice among nurses: An integrative review. International Journal of Nursing Studies, 56, 128-140.

Simamora, Ns Roymond H., \& Kep, M. (2009). Buku ajar pendidikan dalam keperawatan. EGC.

Slameto. (2010). Faktor-Faktor Belajar yang Mempengaruhinya. In Rineka Cipta. Jakarta.

Tilson, Julie K., Kaplan, Sandra L., Harris, Janet L., Hutchinson, Andy, Ilic, Dragan,

Niederman, Richard, Potomkova, Jarmila, \& Zwolsman, Sandra E. (2011). Sicily statement on classification and development of evidence-based practice learning assessment tools. BMC Medical Education, 11(1), 1-10. 